Proceedings of the New Zealand Grassland Association 46: 151- 156 (1985)

\title{
EFFECT OF SHEEP GRAZING REGIME ON PERFORMANCE OF MATUA PRAIRIE GRASS
}

\author{
R.T. ALEXANDER
}

Abstract

Persistency and productivity of irrigated 'Grasslands Matua' prairie grass pastures were measured under four sheep grazing regimes, frequent or infrequent (grazed 3 weekly or 6 weekly) coupled with lax or severe defoliation (grazed to $7.5 \mathrm{~cm}$ or $2.5 \mathrm{~cm}$ ). Matua was also compared with 'Grasslands Nui' and Yates 'Ellett' perennial ryegrasses under frequent severe grazing. These are interim results from two experiments sown in successive years.

There were few consistent differences among grazing treatments of Matua pastures. However, the Matua content of pastures tended to be less under frequent grazing. In the third year of Experiment 1 , infrequent grazing to $2.5 \mathrm{~cm}$ resulted in significantly hlgher annual production than other Matua treatments. 'Eiliett' ryegrass tended to outyield 'Grasslands Nui' in the first year but subsequently there was little difference in yields. The dry matter production of 'Ellett ryegrass was not significantly different from the best Matua treatment in any year.

More herbage was lost through trampling and decay in the infrequently grazed Matua pastures than in the frequently grazed Matua or ryegrass pastures. After three years, all Matua pastures contained more weeds and more volunteer grasses than did ryegrass pastures.

Keywords: prairie grass, Matua, ryegrass, Nul, Ellett, grazing management, lax grazing, severe grazing, irrigation.

\section{INTRODUCTION}

'Grasslands Matua' prairie grass (Bromus willdenowin) was selected and bred for New Zealand conditions and is recognised as a winter active palatable species suitable for dairying (Rumball 1974). That is, it is suited to high fertility soils and rotational grazing with lax defoliation. Matua is less severely affected by grassgrub than perennial ryegrasses and it also re-establishes from natural seedfall in pastures weakened by grassgrub attack in the autumn (East et al. 1980).

In mowlng trials conducted on heavy soils in Canterbury, Matua has produced more than 'Grasslands Nui' perennial ryegrass (Lolium perenne L.) at Rangiora (MAF unpublished), and Lincoln (Fraser 1982). At both sites under an infrequent but severe $(3 \mathrm{~cm}$ above the ground) cutting regime, Matua was superior to the perennial and annual ryegrasses in all seasons.

Little research has been done on grazing Matua with sheep under border-dyke irrigation in Canterbury. The Lolium endophyte and argentine stem weevil (Listronotus bonariensis) problems with ryegrasses are causing farmers to look for alternative grasses. Matua seems to be promising and its use by sheep farmers has increased but the ability of Matua to persist as a perennial is beingiquestioned.

Some comparisons of perennial ryegrasses have shown that 'yields of Yaies 'Ellett' ryegrass pastures were greater than those of 'Nui' ryegrass pastures. Ellett pastures contalned more ryegrass and less white clover (Trifolium repens L.) than Nui pastures (Goold 1982; Percival \& Duder 1983).

These present experiments were designed to measure the productivity and persistence of Matua prairie grass under four sheep grazing managements, namely, 
frequent or infrequent grazing in combination with either severe or lax defoliation. A secondary objective was to compare the production of Nui and Ellett ryegrasses with that of Matua under a frequent and severe grazing regime. Interim results for the first three years are presented in this paper.

\section{MATERIALS AND METHODS}

Site

The experiments were located at the Ministry of Agriculture and Fisheries Research Station at Templeton in Canterbury on a Templeton silt loam soil.

\section{Treatments}

Two identical experiments, each using a completely randomised design with 2 replicates were laid down in consecutive years 1981 and 1982. The experiments included four Matua treatments and a single treatment each of Nui or Ellett ryegrass. The sowing rate of viable seed was 'Grasslands Matua' prairie grass, $30 \mathrm{~kg} / \mathrm{ha}$; 'Grasslands Nui' and Yates 'Ellett' ryegrasses, $20 \mathrm{~kg} / \mathrm{ha}$. 'Grasslands Huia' white clover at $3 \mathrm{~kg} / \mathrm{ha}$, was included with each grass. The prairie grass seed was treated with the fungicides Benlate $(1 \mathrm{~kg} 1200 \mathrm{~kg}$ of seed) and Baytan $(1 \mathrm{~kg} / 20 \mathrm{~kg}$ of seed) in Experiments 1 and 2 respectively. Two grazing frequenices with sheep (every 3 or 6 weeks) at two grazing intensities (to a height of either 2.5 or $7.5 \mathrm{~cm}$ ) were imposed on the Matua. The Nui and Ellett ryegrasses were grazed to $2.5 \mathrm{~cm}$ every 3 weeks. Plots $(40 \mathrm{~m} \times 12 \mathrm{~m})$ were individually fenced border strips.

\section{Establishment}

The total experimental area was cropped with sugarbeet during 1980. Experiment 1 was sown on April 6, 1981 following a five month fallow. The seed was broadcast through a Duncan drill without coulters followed by light harrows. Experiment 2 was sown on February 23,1982 after seventeen months of fallow. It was broadcast using a hand driven seed spinner and lightly harrowed.

\section{Management}

The initial MAF soil "Quick test" (March 1981) showed levels of $\mathrm{Ca} 14, \mathrm{~K} 12, \mathrm{P} 16$, $\mathrm{Mg} 18$ and $\mathrm{a} \mathrm{pH}$ of 5.4 . Experiments 1 and 2 were sown with $100 \mathrm{~kg} / \mathrm{ha}$ of superphosphate. Lime at 5 tha was applied in September, 1981 over Experiments 1 and 2. Annual topdressing was with $250 \mathrm{~kg} / \mathrm{ha}$ of superphosphate applied in the spring. In the three seasons from 1981-82 to 1983-84, plots received six, seven and three irrigations respectively. At each irrigation, approximately $100 \mathrm{~mm}$ of water was applied. No soil moisture measurements have been made.

Yields from sowing to the first grazing were not measured. Pastures were grazed either 14 times (every 3 weeks) or 7 times (every 6 weeks) each year. The grazing duration ranged from 2 to 4 days at a stocking density of 200 to 1000 sheep/ha.

\section{Measurement}

Pasture production was measured with pre- and post- grazing cuts using two to four randomly sited quadrats (each $0.25 \mathrm{~m}^{2}$ ) per plot. All herbage was cut with a shearing handpiece to ground level, bulked per plot and subsampled for dry matter (DM) and species dissection, Seasons were 'spring' September to November (2 cycles of infrequent grazing), 'summer' December to February (2 cycles), 'autumn' March to May $(2$ cycles) and 'winter' from mid May to the end of August (1 extended cycle) when plots were left ungrazed.

Trampled material was defined as the sum of the dead content of the dry matter after grazing minus the dead content of the dry matter before grazing. It was assumed that no dead material was lost through decay or consumed during the grazing period; therefore any increase in dead material over the grazing period was green material which had been trampled and appeared dead, Total green yield after grazing was defined as residual dry matter. 
Plant counts of the sown grasses were taken in September following sowing, using ten quadrats $\left(0.1 \mathrm{~m}^{2}\right)$ randomly sited per plot. Point analysis was used to determine the composition of the pastures in May 1984. Ten groups of 20 points per plot were randomly selected. Grassgrubs were counted in autumn 1983 and 1984, using ten randomly sited $\left(15 \mathrm{~cm}^{3}\right)$ cores per plot. The endophyte and argentine stem weevil infestations were not measured.

\section{RESULTS}

\section{Establishment}

Matua treatments averaged 114 and 80 Matua plants $/ \mathrm{m}^{*}$ in Experiment 1 and 2 respectively. Ryegrass treatments averaged 600 ryegrass plants $/ \mathrm{m}^{2}$ in both experiments. There were no significant differences among Matua treatment plant populations in any year. Similarly there were no significant differences between ryegrass cultivars in any year.

\section{Grassgrubs}

Grassgrub counts showed no significant population differences between treatments during 1983 or 1984 but the population increased from $5 / \mathrm{m}^{2}$ in September 1983 to $300 / \mathrm{m}^{2}$ by May 1984 .

Table 1: YIELD OF TOTAL GREEN AND TRAMPLED HERBAGE (kg DM/ha) AND THE PROPORTION OF SOWN GRASSES, AND WHITE CLOVER OVER THREE YEARS, Experiment 1.

\begin{tabular}{|c|c|c|c|c|c|c|c|}
\hline species & & Intensity & Frequency & $\begin{array}{c}\text { Green } \\
\text { yield }\end{array}$ & $\begin{array}{l}\% \text { Sown } \\
\text { grasses }\end{array}$ & $\begin{array}{l}\% \text { White } \\
\text { clover }\end{array}$ & $\begin{array}{l}\text { Trampled } \\
\text { material }\end{array}$ \\
\hline \multicolumn{8}{|c|}{$1981-82$} \\
\hline Matua & & lax & infrequent & 17100 & 73 & 26 & 5400 \\
\hline Matua & & severe & infrequent & 17700 & 68 & 25 & 3500 \\
\hline Matua & & $\operatorname{lax}$ & frequent & 15400 & 52 & 46 & 2100 \\
\hline Matua & & severe & frequent & 18300 & 52 & 39 & 2200 \\
\hline Nui & & severe & frequent & 13500 & 82 & 16 & 1600 \\
\hline Ellett & & severe & frequent & 17400 & 80 & 16 & 1400 \\
\hline & LSD & $5 \%$ & & 2400 & 48 & 33 & 3200 \\
\hline \multicolumn{8}{|c|}{1982.83} \\
\hline Matua & & $\operatorname{lax}$ & infrequent & 11200 & 55 & 35 & 2800 \\
\hline Matua & & severe & infrequent & 14200 & 54 & 43 & 1000 \\
\hline Matua & & lax & frequent & 12200 & 46 & 35 & 200 \\
\hline Matua & & severe & frequent & 12900 & 50 & 41 & 300 \\
\hline Nui & & severe & frequent & 13500 & 61 & 35 & 500 \\
\hline Ellett & & severe & frequent & 12000 & 60 & 30 & 1800 \\
\hline & LSD & $5 \%$ & & 8000 & 40 & 39 & 1800 \\
\hline \multicolumn{8}{|c|}{1983.84} \\
\hline Matua & & $\operatorname{lax}$ & infrequent & 13500 & 72 & 16 & 2700 \\
\hline Matua & & severe & infrequent & 17200 & 75 & 17 & 1300 \\
\hline Matua & & $\operatorname{lax}$ & frequent & 14700 & 52 & 16 & 300 \\
\hline Matua & & severe & frequent & 14000 & 41 & 43 & 600 \\
\hline Nui & & severe & frequent & 16300 & 85 & 7 & 1300 \\
\hline Ellett & & severe & frequent & 17400 & 88 & 11 & 900 \\
\hline \multicolumn{2}{|r|}{ LSD } & $5 \%$ & & 2300 & 39 & 18 & 1700 \\
\hline
\end{tabular}

1 Refer to methods for definition of 'trampled' material 


\section{Annual Production, Experiment 1}

Mean annual green yields of all pastures for the three growing seasons were 16600, 12700 and $15500 \mathrm{~kg}$ DM/ha (Table 1).

In 1981-82, the frequently and laxly grazed Matua pasture was significantly $(P<0.05)$ inferior to the other Matua pastures, especially those frequently and severely grazed. However, by 1983-84 the infrequently and severely grazed Matua pasture had produced more than all other Matua pastures for green DM production $(\mathbf{P}<0.05)$. All yields were lower in 1982-83, although the proportion of white clover was generally higher than in other years (Table 1).

In the first and third years, Matua constituted about $70 \%$ of the infrequently grazed pastures while white clover made up $26 \%$ and $17 \%$ respectively. In the second year, the proportion of Matua was lower and white clover was higher. In contrast, the proportion of Matua under severe frequent grazings was only $52 \%$ in the first year and this decreased to $41 \%$ in the third year. White clover remained stable at about $40 \%$ (Table 1). Ellett outyielded Nui $(P<0.05)$ for total production of green herbage during 1981-82.

Average residual yields after grazing for Matua treatments In 1982-83 and 1983-84 were, under infrequent grazing; lax (1130 kg DM/ha) severe (850), and under frequent grazing; lax (1010), severe (630). Frequently and severely grazed ryegrass pasture were similar at $630 \mathrm{~kg} \mathrm{DM} / \mathrm{ha}$.

The amount of trampled material was extremely varlable, but over the three years, this averaged as much as 18\% of total green yield in the Infrequently grazed Matua pastures, and only $5 \%$ and $9 \%$ in the frequently grazed Matua and ryegrass pastures respectively (Table 1).

Table 2: YIELD OF TOTAL GREEN AND TRAMPLED HERBAGE (kg DM/ha) AND THE PROPORTION OF SOWN GRASSES, AND WHITE CLOVER OVER TWO YEARS, Experiment 2.

\begin{tabular}{|c|c|c|c|c|c|c|}
\hline Specles & Intensity & Frequency & $\begin{array}{l}\text { Green } \\
\text { vield }\end{array}$ & $\begin{array}{r}\% \text { Sown } \\
\text { orasses } \\
\end{array}$ & $\begin{array}{l}\% \text { White } \\
\text { clover }\end{array}$ & $\begin{array}{c}\text { Trampled } \\
\text { material }\end{array}$ \\
\hline \multicolumn{7}{|c|}{$1982-83$} \\
\hline Matua & $\operatorname{lax}$ & infrequent & 15200 & 64 & 17 & 2300 \\
\hline Matua & severe & infrequent & 13400 & 59 & 27 & 3500 \\
\hline Matua & $\operatorname{lax}$ & frequent & 10100 & 43 & 28 & 1100 \\
\hline Matua & severe & & 15000 & 47 & 17 & 200 \\
\hline Nui & severe & If frequent req & uent 10800 & 77 & 20 & 40 \\
\hline Ellett & severe & frequent & 13700 & 84 & 11 & 100 \\
\hline LSD & $5 \%$ & & 4000 & 20 & 18 & 2000 \\
\hline \multicolumn{7}{|c|}{$1983-84$} \\
\hline Matua & lax & infrequent & 14300 & 64 & 18 & 4300 \\
\hline Matua & severe & infrequent & 15400 & 56 & 34 & 3600 \\
\hline Matua & $\operatorname{lax}$ & frequent & 15100 & 40 & 29 & 1400 \\
\hline Matua & severe & frequent & 15600 & 48 & 28 & 0 \\
\hline Nui & severe & frequent & 16700 & 75 & 23 & 400 \\
\hline Ellett & severe & frequent & 16900 & 90 & 12 & 300 \\
\hline LSD & $5 \%$ & & 5400 & 15 & 13 & 2000 \\
\hline
\end{tabular}

\section{Annual Production, Experiment 2}

Variability in this experiment has remained high (Table 2). Mean annual green yields for the two growing seasons were 13000 and $15700 \mathrm{~kg}$ DM/ha (Table 2). 
The Matua frequently and laxly grazed pasture again yielded significantly lower $(P<0.05)$ than other Matua treatments in the first year. Sown grass percentages showed the same trends as in Experiment I. There were no significant differences in yields between Nui and Ellett in either year although Nui pastures contained more white clover (Table 2).

Average residual yields after grazing for 1982-83 and 1983-84 for Matua treatments were, infrequent grazing - lax (1360 kg DM/ha), severe (1150); frequent grazing - lax (1 $11 \mathrm{lO})$, severe (670). Severely grazed Nui was $540 \mathrm{~kg} \mathrm{DM} / \mathrm{ha}$ and Ellett was $700 \mathrm{~kg} \mathrm{DM} / \mathrm{ha}$. The total trampled green material averaged $23 \%$ in the infrequently grazed Matua pastures, and only $5 \%$ and $1 \%$ in the frequently grazed Matua and ryegrass pastures respectively (Table 2).

\section{Seasonal Production}

The frequently grazed Matua has grown best in autumn and winter while the infrequently grazed Matua was best in spring and summer. The frequently grazed Matua pastures opened up in the first summer and became clover dominant. In Experiment I, the frequently and severely grazed Matua produced more $(P<0.05)$ than Ellett (3000 of $1300 \mathrm{~kg} \mathrm{DM} / \mathrm{ha}$ ) during winter 1982, while in the winter of 1983 Nui produced significantly $(P<0.05)$ more than the same Matua treatment $(1900$ of 1000 $\mathrm{kg} \mathrm{DM} / \mathrm{ha}$ ). There was no consistent seasonal superiority of either Nui or Ellett.

Table 3: POINTi ANALYSIS RESULTS: PERCENT POINTS PER PLOT BASED ON 200 HITS PER PLOT (June 1984)

\begin{tabular}{|c|c|c|c|c|c|c|c|c|}
\hline Species & Intensity & Frequency & Matua & Ryegrass & $\begin{array}{l}\text { White } \\
\text { clover }\end{array}$ & $\begin{array}{c}\text { Weeds \& } \\
\text { other } \\
\text { grasses }\end{array}$ & \& Litter & $\begin{array}{l}\text { Bare } \\
\text { ground }\end{array}$ \\
\hline
\end{tabular}

\section{Experiment 1:}

\begin{tabular}{|c|c|c|c|c|c|c|c|c|}
\hline Matua & Lax & Infrequent & 30 & 8 & 15 & 5 & 25 & 16 \\
\hline Matua & Severe & Infrequent & 31 & 6 & 16 & 9 & 18 & 19 \\
\hline Matua & Lax & Frequent & 30 & 9 & 24 & 5 & 15 & 17 \\
\hline Matua & Severe & Frequent & 14 & 2 & 27 & 34 & 8 & 16 \\
\hline Nui & Severe & Frequent & 0 & 60 & 8 & 1 & 15 & 16 \\
\hline Ellett & Severe & Frequent & 0 & 63 & 10 & 1 & 12 & 14 \\
\hline & SSD $5 \%$ & & 13 & 15 & 10 & 7 & 14 & 10 \\
\hline
\end{tabular}

\section{Experiment 2:}

\begin{tabular}{|c|c|c|c|c|c|c|c|c|}
\hline Matua & Lax & Infrequent & 19 & 7 & 17 & 3 & 30 & 24 \\
\hline Matua & Severe & Infrequent & 19 & 6 & 19 & 0 & 26 & 30 \\
\hline Matua & Lax & Frequent & 22 & 19 & 29 & 7 & 10 & 14 \\
\hline Matua & Severe & Frequent & 24 & 5 & 29 & 11 & 6 & 26 \\
\hline Nui & Severe & Frequent & 1 & 49 & 24 & 3 & 5 & 19 \\
\hline Ellett & Severe & Frequent & 0 & 65 & 12 & 1 & 5 & 17 \\
\hline & LSD $5 \%$ & & 8 & 13 & 18 & 8 & 11 & 16 \\
\hline
\end{tabular}

\section{Polnt Analysis}

Point analysis results (Table 3 ) show that after 3 years the frequently and severely grazed Matua pasture in Experiment 1 had significantly $(P<0.05)$ less sown grass and more weeds and other grasses than the other pastures. Weeds and other grasses present in the pastures were mainly dock (Rumex obtusifolius), annual poa (Poa annua), barley grass (Hordeum murlnum) and ryegrasses (Lollum spp.). In Nui and Eliett pastures the percentage of sown grasses were higher while the white clover percentage was lower than in Matua pastures. 


\section{DISCUSSION}

These experiments have shown that Matua will establish, persist and maintain production under a controlled six week rotational grazing system and good growing conditions for at least three years. The primary cause of yield differences between years was probably the variable farm irrigation schedule, and the fact that 198384 was an exceptionally good year for pasture growth in Canterbury.

The Matua pastures have shown differing patterns of production over the two or three years. The performance of Matua under infrequent severe grazings has been consistently good over the main growing season whereas production under infrequent lax grazings has declined. In the frequently and severely grazed pasture, the Matua has been partly replaced by white clover, annual poa, and barley grass. These problems were lessened by infrequent and severe grazing.

Reseeding of the Matua was not measured but it appears it could not compete with the volunteer ryegrass and barley grass at filling in the gaps. A reversal of the ingress of ryegrass, other grasses and weeds into the Matua pastures is imperative if a Matua sward is to persist indefinitely. Present indications from these trials are that altering the rotation length would not halt the ingress. Under the six weekly rotation the pasture grew up to $60 \mathrm{~cm}$ tall allowing the Matua to dominate the sward, as in a dairying type pasture as recommended by Rumball (1974). A high proportion of this growth was trampled to the ground, dirtied, and not consumed compared with the resilient shorter ryegrass pastures where large losses due to trampling did not occur. The soft wide and long leaf of Matua was a disadvantage under sheep grazing but this may not be so under cattle grazing. These management problems may be difficult to solve under a farming situation.

The persistence of sown grass and clover species is of great concern, and the performances of Matua under these present contrasting managements will be monitored for some years yet.

\section{ACKNOWLEDGEMENTS}

The author is grateful to Dr J.E. Radcliffe for agronomic advice, Mr D.J. Saville for biometrical advice, herbage laboratory staff at Winchmore for dissection and Templeton farm staff for cooperation in running the experiment.

\section{REFERENCES}

East, R.; Kain, W.M.; Douglas, J.A. 1980. Proc. N.Z. Grass/d Ass. 41: 105-115; Fraser, T.J. 1982. N.Z. J. exp. Agric. 10: 235237.

Goold, G.J. 1982. Proc. N.Z. Grassid Ass. 43: 118-124.

Percival, N.S.; Duder, F.R. 1983. Ibid 44: 81.90.

Rumball, W. 1974. N.Z. J. exp. Agric. 2: $1-5$. 